\title{
Planning for Ex-Landfill Redevelopment: Assessing What Community Have in Mind
}

\author{
Mazifah Simis ${ }^{1} \&$ Azahan Awang ${ }^{1}$ \\ ${ }^{1}$ Faculty of Social Science and Humanities, National University of Malaysia (UKM), Malaysia \\ Correspondence: Mazifah Simis, Environmental Management Programme, Faculty of Social Science and \\ Humanities, National University of Malaysia (UKM), 43600 Bangi, Selangor, Malaysia. E-mail: \\ mazsimis1973@gmail.com
}

Received: January 4, 2015 Accepted: February 9, 2015 Online Published: May 15, 2015

doi:10.5539/ass.v11n15p136 URL: http://dx.doi.org/10.5539/ass.v11n15p136

\begin{abstract}
Malaysia, a fast growing developing country is now facing the issue of inadequate urban spaces for future development, which leads to the need to redevelop the brownfield, particularly ex-landfills. A total of 296 ex-landfills have been planned to undergo redevelopment by the year 2020. Although there is a policy for ex-landfill development, a question arises if the policy reflects the needs of the society as the end-recipient that determines the success of the planned development. Therefore, this study was carried out to assess what the community has in mind as a way to identify the community needs in ensuring the success of the future development of ex-landfill. Based on the objectives to identify the perceptions of the community on (i) ex-landfill issues, (ii) the appropriate type of re-development for the ex-landfills, and (iii) the function of the public park in ex-landfills, which have been the main priority of the development type considered by the government, this study produced a priority ranking result that could assist the urban administrator or specifically the Local Authorities in Malaysia to plan an effective and an acceptable development of the ex-landfill for the benefits of current and future communities.
\end{abstract}

Keywords: brownfield, ex-landfill redevelopment, development policy, community needs, efficient planning

\section{Introduction}

Changing of urban space, scarcity of the greenfield areas for future development and the increasing number of the urban population are all the reasons behind the need to redevelop brownfield for the benefits of the economy, social and environment (Heberle \& Werstedt, 2006; Adam et al., 2010). As an emerging developing country in the South East Asia with the rate of urbanization surpassing 70\% (Liu, 2013) and two-thirds from its population are urban dwellers (UNDP Malaysia, 2012), the need to redevelop brownfield areas has been mentioned specifically in its developmental policy - the National Urban Policy (Department of Town and Country Planning Peninsular Malaysia, 2010). As the policy is specifically designed to drive Malaysia towards the implementation of urban development, National Urban Policy has urged the need for the Local Authorities, which are the authoritative administrators in Malaysia, to identify, plan, prepare the development programme, and redevelop the brownfield within the urban areas.

With regards to that matter, this study gave special attention to Category B Brownfield in the Malaysian development context, which is ex-landfill. The increased number of ex-landfill sites within the vicinity of urban areas and mainly at the urban residential areas due to the impact of urbanization process and urban sprawl that have caused the expansion of urban area, urged the redevelopment of ex-landfill to be included in Malaysia's physical planning development in 2004 (Ministry of Housing and Local Government, 2004; National Physical Planning Council, 2004). This highlights the importance of ex-landfill redevelopment in the context of sustainable urban development in Malaysia. On the other hand, due to the fact that until now no journal article has been published regarding the concerns of the Malaysian community to this area, a question arises whether the needs of the community have been taken into account?

Thus, this study was aimed to function as a background study to identify the need for ex-landfill redevelopment based on the community's thoughts or perception. Three objectives were formed: (i) to identify the perceptions of the community on the issues of ex-landfill that influence their acceptance on any recommendation to redevelop the ex-landfill, (ii) to identify the perceptions of the community on the appropriateness of the type of 
ex-landfill redevelopment, and (iii) to identify the function of the development of public park on the ex-landfill according to the community needs and priorities. Through the achievement of all the three objectives, it is hoped that this study would be able to assist the government, especially the Local Authories, to formulate a planning strategy for ex-landfill development that is able to address the concerns expressed by the community. With these in mind, the redevelopment proposal plan of 296 ex-landfills, which is expected to be implemented by 2020, will not only be well-accepted, but may also lead to the enhancement of the Malaysians' quality of life.

\section{Literature Review}

\subsection{Brownfield and the Role of the Community as the Redevelopment Stakeholder}

Currently, brownfield is a new field of study in urban development due to the issue of deteriorating urban greenfield for future developments and the location of brownfield at the vicinity of urban areas that have created a need to be redeveloped (Doerle, 2012). Brownfield is defined by the United States Environmental Protection Agency (2002) as 'the lands that have been once used industrially or commercially and are now abandoned due to environmental pollutions'. However, according to Armin \& Hoda (2013), until now, there is no specific consensus on the definition of brownfield. These results from the different perceptions of each country towards the function of brownfield redevelopment are based on the different geographical factors, social needs, economic needs, and also the impact of the importance of brownfield to an organization or institution.

According to RESCUE (2005), the redevelopment of brownfield should be based on the concept of brownfield sustainability. Four dimensions, which are (i) ecology, (ii) economy, (iii) social, and (iv) institution (Figure 1) need to be integrated in forming the sustainability concept, which is defined as a management, rehabilitation, and return to beneficial use of brownfields in such a manner as to ensure the attainment and continued satisfaction of human needs for present and future generations in environmentally sensitive, economically viable, institutionally robust, and socially acceptable ways within the particular regional context'.

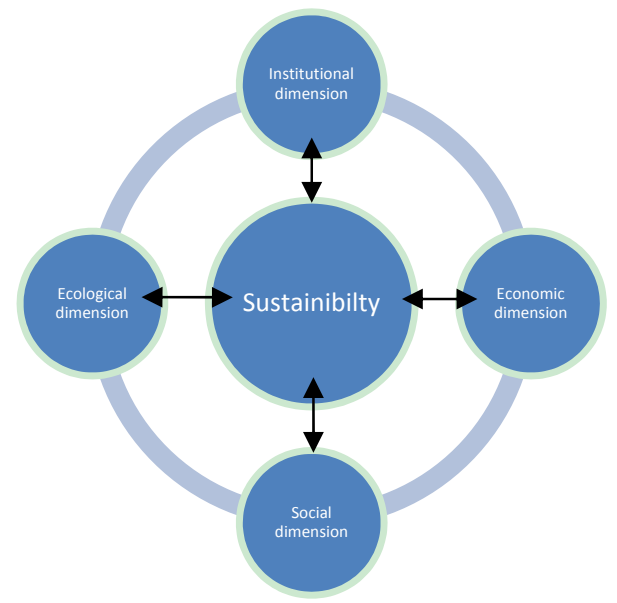

Figure 1. The dimensions of sustainability in the brownfield redevelopment Resource: RESCUE 2005

The concept of sustainable brownfield development indirectly justifies the role of the community as the stakeholder. The 'community needs' need to be accounted in each aspect of planning, proposals of development or decisions-making in regards to the ex-brownfield redevelopment within their neighborhood area. Therefore, Bernstan et al. (2013) and Letang \& Taylor (2012) acknowledged the importance of the perception study in producing data that are able to assess the needs and status of acceptance of the community. By acknowledging what the community thinks about the issues of a certain development and what they need, they concluded that 'any development proposal will get support from the community, and could ensure the effectiveness and success of the programme'.

\subsection{Brownfield and Ex-Landfill in Malaysia}

In the context of Malaysia, brownfield is defined as an area that has been developed, but abandoned or neglected, or which has a development structure that is already obsolete or a development area which is not fully completed and abandoned (Department of Town and Country Planning Peninsular Malaysia, 2012). Brownfield could possibly mean a contaminated area, covering abandoned buildings or buildings which are already completed but not sold in the period of more than 10 years, either on a government land or private land. In order to facilitate the 
planning and development in Malaysia, brownfield is divided into six categories according to the types of areas (Table 1).

Table 1. The categories of brownfield in Malaysia

\begin{tabular}{cl}
\hline $\begin{array}{c}\text { Category } \\
\text { of areas }\end{array}$ & Types of areas \\
\hline A & Former mines / quarries. \\
B & Ex-landfill areas that are full of solid wastes / no longer in use permanently. \\
C & Factory / business / housing / institution / areas that have been abandoned for more than 10 years. \\
D & Incompleted and abandoned development projects in the period of development of more than 10 years. \\
E & Buildings / rows of completed building blocks but abandoned for more than 10 years. \\
F & Former depot / public transportation stations, infrastructural facilities, and utilities. \\
\hline
\end{tabular}

Source: Department of Town and Country Planning Peninsular Malaysia 2012

The expansion of urban area is due to the impact of fast-paced growth of urbanization and urban sprawl in Malaysia has led to the category B brownfield, which was previously located at the rural area or outside the urban vicinity, now becomes part of the urban image and the urban settlement's surrounding environment. The results of comparison analysis based on a study conducted by the Ministry of Housing and the Local Government (2004) and the National Solid Waste Department (2012) showed the increase in quantity and urban space coverage of ex-landfill, which is defined as 'a non-operating landfill, where waste disposal activities have been laid off or completed' (Ministry of Housing and Local Government, 2004).

In 2003, there were 115 ex-landfills in Malaysia with an estimation of $50.0 \%$ of them were located within the urban area. The number of ex-landfill had increased to 131 in 2012, and it has been expected to become 296 when all the existing landfills in Malaysia close their operation by 2020 . From the total of 296, more than $70.0 \%$ of those future ex-landfills are expected to be located in the urban areas and urban settlements, whereby 13 of them have been identified to have an average of 8.0 to 10.0 hectares. Besides becoming the cause of increasing number of urban brownfield, the ex-landfills have also been identified as an issue that sparks worries to the local population within the ex-landfill areas (Chun-Yang \& Talib 2006). The existence of ex-landfill as their neighborhood surrounding area creates issues of foul odors, leachate, and landfill gas pollution, whereby the locals associate them with deterioration of health and quality of life. Amid those issues, ex-landfills, especially the ex-landfills which are located within the urban areas or also known as urban ex-landfill, have been identified as assets to address the issue of greenfield for future developments (Department of Town and Country Planning Peninsular Malaysia, 2010) and an alternative to address the inadequacy of urban green spaces provisions according to the standard of 2 hectares per 1,000 urban population (National Landscape Department, 2010a).

\subsection{The Ex-Landfill Development Policy and Proposal of Ex-Landfill as Public Park in Malaysia}

The guideline for safe closure and rehabilitation of Municipal Solid Waste landfill sites (Ministry of Housing and Local Government, 2004) and the decisions of the National Physical Planning Council (2004) act as the basic policy for ex-landfill development in Malaysia. The guideline for safe closure and rehabilitation of Municipal Solid Waste landfill sites proposes that the re-development of ex-landfill is carried out through limited development methods. It means the type of ex-landfill redevelopment is limited to five, namely (i) agricultural areas, (ii) parking areas and roads, (iii) public parks, (iv) housing areas, and (v) commercial or industrial areas. This guideline also grants the power to the Local Authority as the urban administrator to decide on the suitability of development to be implemented.

The limited development proposal and the determination over the suitable type of ex-landfill development are then further detailed by the National Physical Planning Council (2004). Based on the justification of "community security and wellbeing", the Council, which is led by the Prime Minister, has decided that public parks should become the priority for redevelopment of ex-landfills in Malaysia. The Council also has decided that the development of housing and commercial or industrial areas at the ex-landfill sites needs a detailed study before it can be implemented. In the context of landscape planning, the decision of the National Physical Planning Council becomes a specific justification to justify the proposal to redevelop public parks at the ex-landfill sites.

The importance to develop public parks at ex-landfill sites is then detailed in the guideline to conserve ex-landfills as public parks (National Landscape Department, 2010a) and Planning guideline for brownfield redevelopment (Department of Town and Country Planning Peninsular Malaysia, 2012). The development of public parks at ex-landfill sites is stated to serve as an alternative in dealing with the issue of inadequate urban 
spaces for the development of new public parks. This is due to the fact that the major urban areas and cities in Malaysia are currently facing issues of changing of land use status, impact of the rapid development of urban physical, and economic infrastructure that create the incapability of the Local Authority to provide adequate urban green spaces based on urban population rate (Abd Mutalib, 1999; Puteri Haryati et al., 2013). As an impact of the local authority's incapability, a study in 1999 by Ismail showed that Kuala Lumpur, the capital of Malaysia, is only able to provide 0.4 hectare of open green spaces for 1,000 urban population. A recent study by PEMANDU (2010) had identified that Kuala Lumpur could only provide 12 square meters of green space for each individual. Even though the study by PEMANDU has resulted in the creation of Greater Kuala Lumpur programme, it is also viewed as a critical indicator to the needs of sufficient urban parks.

The issue of inadequate urban green spaces has become more critical as the planning standard of 2 hectares of open spaces per 1,000 urban population has been accepted as an indicator to the achievement of the status of sustainable urban development and Malaysia as a Developed Country (Department of Town and Country Planning Peninsular Malaysia, 2007; Department of Town and Country Planning Peninsular Malaysia, 2010). Meanwhile, until 2012, there were only 13,626 hectares of public parks in Malaysia (National Landscape Department, 2012) compared to the 6.81 million of urban population (National Statistics Department, 2012). Therefore, development of public parks at ex-landfill sites has been targeted to give an additional 450 hectares of recreational areas for 225,000 urban population in Malaysia by 2020 .

In general, the priority of the ex-landfill development as public parks in Malaysia can be explained in the formation of the theoretical framework (Figure 2). Through the acceptance and support from the community towards public park development on ex-landfills, the existence of urban ex-landfill sites can be reduced, the number of urban green areas can be increased, and it may also become the causal factor to the existence of sustainability through increased comfort in the surrounding urban habitat and community's quality of life. Thus, the community perception study in regards to the priority of ex-landfill development types and the function of public park development in ex-landfills determines the level of community's acceptance towards the proposal of developing ex-landfills as public parks.

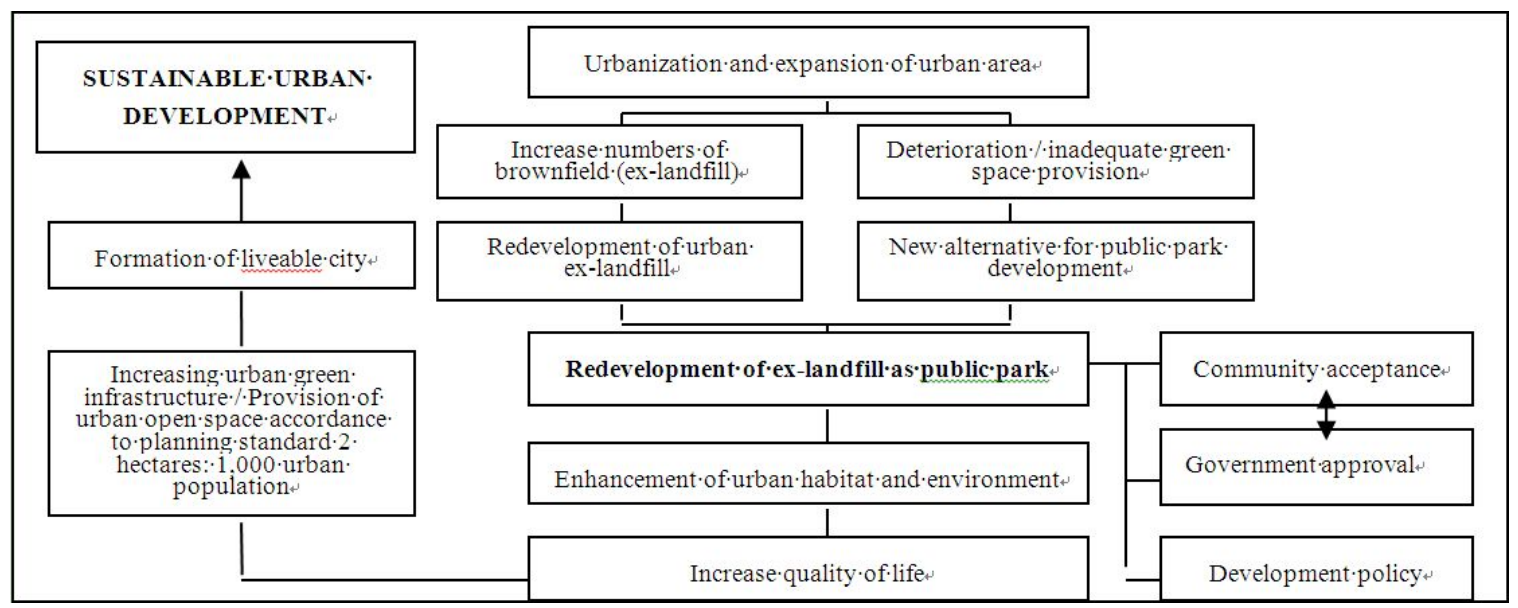

Figure 2. Theoretical framework of ex-landfill development as the public parks in Malaysia

\section{Methodology}

The literature review recognized the fact that planning for ex-landfill redevelopment within the human habitat needs an approval from its residents as the end stakeholder of the development. Therefore, in order to achieve the study objectives, surveys with community living within the selected ex-landfill sites as the study respondents were conducted.

\subsection{Data Collection}

Data collection was done using the questionnaire-survey method. The questionnaire was divided into 2 sections: (i) demographic information, including gender, age, housing area location, type of housing occupied, and the duration of occupation, and (ii) community perceptions towards the ex-landfill issues, the type of ex-landfill redevelopment based on its priority and the function of the public park redevelopment in ex-landfills sites. The type of questions for section (ii) was closed-ended questions based on the selection of ranking order. A total of 367 questionnaires were given to a total of 367 selected respondents living within the study areas during the period of May to July 2014. 


\subsection{Research Sample}

Based on the sample size calculation by Krejcie and Morgan (1970)with 95\% confidence level, a total of 367 heads of household from 17,204 occupied housing units in five study areas, namely (i) Jinjang Utara ex-landfill, (ii) Banting ex-landfill, (iii) Paka Sg.Besi ex-landfill, (iv) Indera Mahkota (Kuantan) ex-landfill and (v) Ayer Hitam ex-landfill had been selected as the sample size for this study (Table 2). The sample size was randomly selected within each of the study area to give an equal opportunity for the community to become the respondents. The study areas were selected based on the justification that they have exceeded the minimum period ( 5 years of closing) prescribed by the Ministry of Housing and Local Government (2004) suitable for public park's development. Meanwhile, the setting of 1.0 kilometer radius as the boundary of the study areas is in accordance to the United States of Environmental Protection Agency's standard range for collecting observational landfill data, and also referring to the opinions of Lisa et al. (2003) and Robert (2000). Both of them claimed that the study area to access landfill impact should be limited to within 1.0 kilometer radius of the landfill area in order to produce accurate data.

Table 2. Population size and sample size according to the study areas

\begin{tabular}{|c|c|c|c|c|}
\hline Study Area & $\begin{array}{l}\text { The number of occupied } \\
\text { housing unit per study area } \\
\text { (Population size) }\end{array}$ & $\begin{array}{l}\text { Percentage } \\
\quad(\%)\end{array}$ & $\begin{array}{l}\text { The number of } \\
\text { respondents per study } \\
\text { area (sample size) }\end{array}$ & $\begin{array}{l}\text { Percentage } \\
\quad(\%)\end{array}$ \\
\hline $\begin{array}{l}\text { i) Jinjang Utara } \\
\text { ex-landfill }\end{array}$ & 5,492 & 31.92 & 120 & 31.91 \\
\hline ii) Banting ex-landfill & 502 & 2.92 & 11 & 2.93 \\
\hline $\begin{array}{l}\text { iii) Paka (Sg. Besi) } \\
\text { ex-landfill }\end{array}$ & 3,981 & 23.14 & 87 & 23.14 \\
\hline $\begin{array}{l}\text { iv) Indera Mahkota } \\
\text { (Kuantan) ex-landfill }\end{array}$ & 2,059 & 11.97 & 45 & 11.97 \\
\hline $\begin{array}{l}\text { v) Ayer Hitam } \\
\text { (Puchong) ex-landfill }\end{array}$ & 5,170 & 30.05 & 113 & 30.05 \\
\hline Total & 17,204 & 100.00 & 376 & 100.00 \\
\hline
\end{tabular}

\subsection{The Determination of Variables}

Five variables were studied to identify the ex-landfill issues (i) fire and explosion caused by landfill gases, (ii) risks of land collapse and soil subsidence around the ex-landfill sites, (iii) foul odor produced by the ex-landfill sites, (iv) water contamination caused by leachate from the ex-landfills, and (v) risks of health and security faced by the community around the ex-landfills. All these five variables are stated by Hertzman et al. (1987) and Chung-Yang \& Talib (2006) to be major problems in the landfills and are identified as issues that caused community vacillation if not being managed properly by the developers. As for the types of suitability of ex-landfill redevelopment, the types of development as proposed in the limited development policy (Ministry of Housing and Local Government 2004) were selected as the study variable. The types of development include agricultural areas, parking areas and roads, public parks, housing areas, and commercial or industrial areas.

The function of the public parks and brownfield redevelopment was integrated as variables in the study of the function of public parks in ex-landfills. Ten variables were selected based on their importance due to the results from previous researches. The importance of the function of the public parks as outdoor recreation areas and social areas of the locals, as well as the improvement of the neighborhood areas are stated by Melasutra \& Mohd Zulfa (2006) in community perception study towards the function of neighborhood parks to the urban population in Malaysia. The function of public parks as an added-value to the property and visual aesthetic value to the surrounding area, buffer area, and conservation area for ecology and environment has been emphasized by the National Landscape Department (2010a; 2010b). The function of the public park development as a contributor to the enhancement of health, security, and wellbeing of the community has been identified in many studies (Dale \& Newman, 2009; IFPRA, 2013), and it has also been mentioned by many researchers as the purpose of brownfield redevelopment (De Sausa, 2003; Siikamaki \& Wernstedt, 2008; Berman \& Forrester, 2013).

\subsection{Formula to Determine the Rank Order by Priority}

Mathematical calculation to determine the value of percentage was adopted as the formula to determine the rank of priority.

Rank of priority: The total value of sub-component

The total value of the overall component 
The total value of sub-component is referring to the total weightage value for each sub-component. Weightage value is used to determine the level of importance of the sub-component based on the community perception, where:

i. Value 1 to 5 for ex-landfill issues. 5 represents the issue that is extremely hesitant to the community, 4 for hesitant, 3 for not really hesitant, 2 for unhesitant, and 1 for extremely unhesitant.

ii. Value 1 to 5 for the suitability of the type of ex-landfill development. 5 represents the type of development that is extremely suitable type for ex-landfill redevelopment based on community's opinion, 4 for suitable, 3 for not really suitable, 2 for unsuitable, and 1 for extremely unsuitable.

iii. Value 1 to 10 for the priority scale of the function of public parks in ex-landfills based on community opinion, where 1 is the lowest priority and 10 is the highest priority.

Meanwhile, the total value of the overall component refers to the total value of the overall weightage derived from each sub-component value. Based on weightage value in each sub-component's category, the total value for ex-landfill issues was 5,686 for ex-landfill issue, 5,642 for the suitable type of ex-landfill development, and 21,194 for the function of public park development on ex-landfills.

\section{Result and Discussion}

Graphs were used to show the priority of rank order in achieving the three objectives of the study, namely:

i. To identify the perception of the community towards the issues of ex-landfill.

ii. To identify the perception of the community towards the suitability type of ex-landfill re-development.

iii. To identify the perceptions of the community towards the function of the public park development in the ex-landfill sites.

Figure 3 shows the order of priority for ex-landfill issues, based on the community perception. According to the ranking, bad odor is ranked as the number one issue, where $25.98 \%$ of the respondents perceived it as the issue that gives most hesitant to the neighborhood community and needs to be solved before any development on ex-landfill could take place. It is followed by the health and safety risks $(21.75 \%)$, water pollution caused by leachate (19.52\%), fire and explosion (17.05\%) and rubble and soil subsidence (15.69\%).

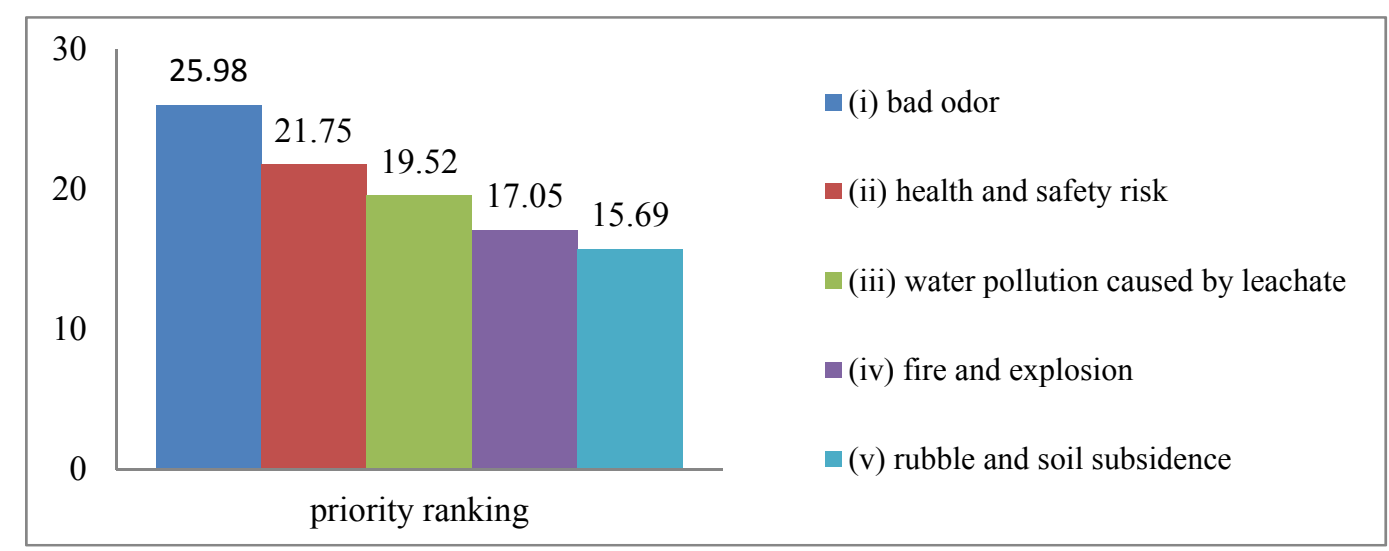

Figure 3. The order of priorities for ex-landfill issues

This result is consistent with the study outcome obtained by Chun-Yang \& Talib (2006) and Zaini et al. (2011), which concluded that foul odor was commonly perceived by the community as the main issue due to the level of exposure that the community was subjected to towards the issue as compared to other issues. As stated by Bernstan et al. (2013), it could be concluded that the odor issue needs to be overcome prior to the ex-landfill development, which indirectly would be able to elevate the level of community's confidence towards the proposed development. Besides the odor issue, special attention also needs to be given to the issue of health and safety risks, which was placed as second in the priority ranking order. This is due to the fact that there is a relationship between bad odor and deteriorating of health and safety, as perceived by the community (Chung-Yang \& Talib 2006).

Figure 4 shows the order of priority for the types of ex-landfill redevelopment, based on the suitability as perceived by the community. According to the ranking, the public park is perceived as the most suitable type for ex-landfill redevelopment. Public park is ranked first in the order of priority with the acceptance rate of $27.67 \%$. 
It is followed by parking areas and roads (rank second with the acceptance rate of 22.90\%), housing areas (rank third with the acceptance rate of $17.76 \%$ ), agricultural areas (rank fourth with the acceptance rate of $16.85 \%$ ) and commercial or industrial area (rank fifth with the acceptance rate of $14.85 \%$ ).

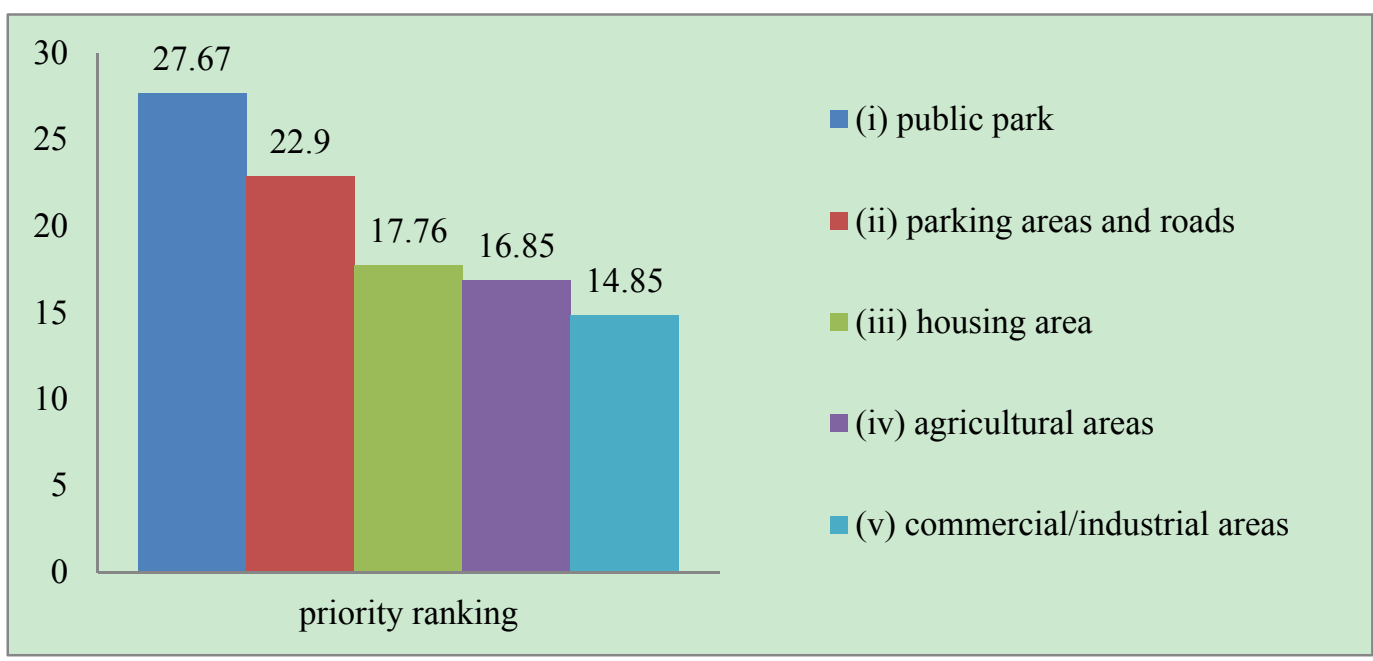

Figure 4. The order of priority for the types of ex-landfill development

These results indirectly serve as an indicator of the level of community's acceptance towards the policy of public park as the main priority development in the type of ex-landfill redevelopment in Malaysia (National Physical Planning Council 2004). These results also indicate that the community's acceptance towards the proposal of public park development at the ex-landfill is in line as suggested by the National Landscape Department (2010).

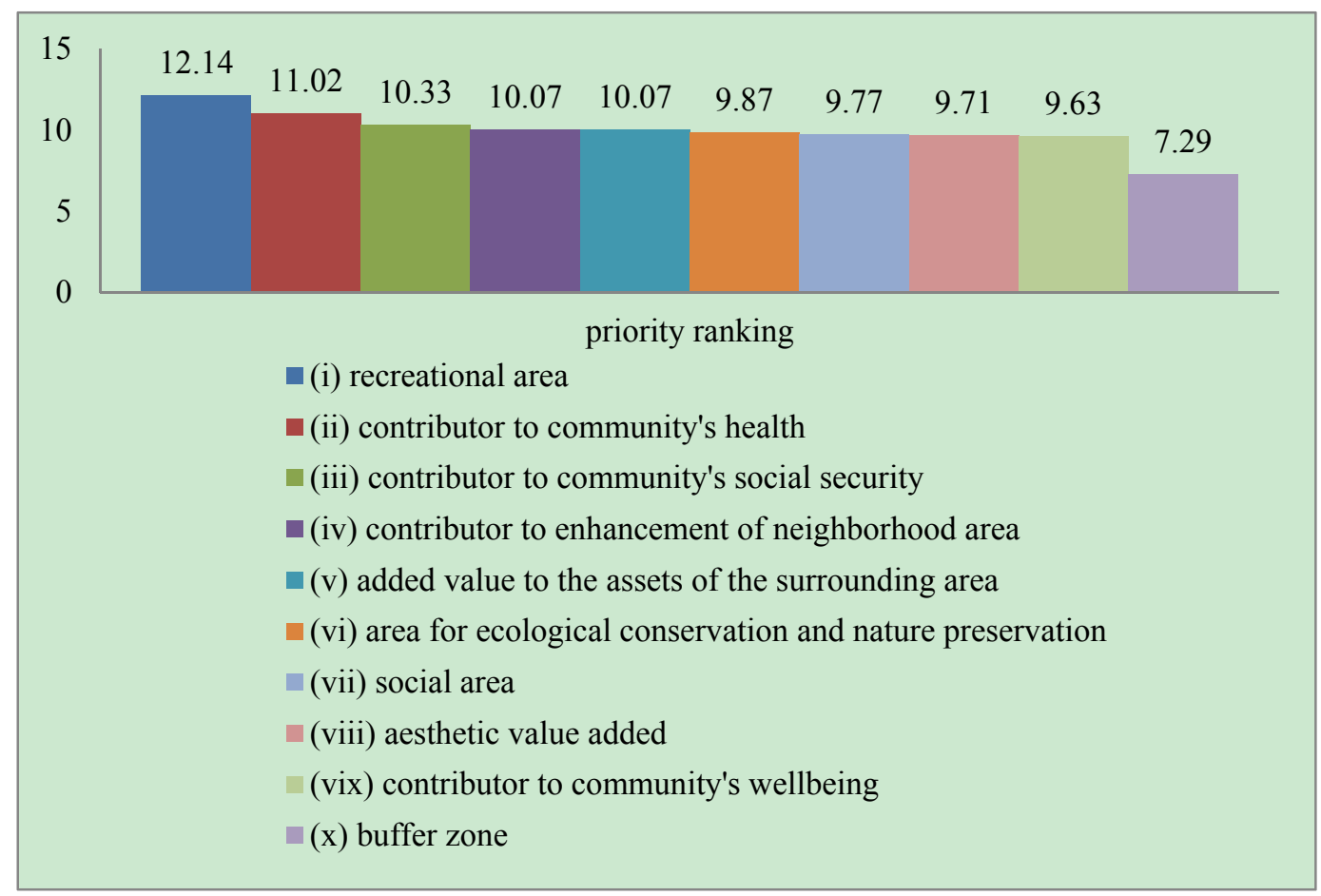

Figure 5. The order of priority function for public parks at ex-landfill sites

Figure 5 shows the order of priority for public parks on ex-landfill functions based on the opinion of the community. According to the community, the main function of public park on ex-landfill or rank first for public park on ex-landfill function is as a recreational area. It means that the development of public park on ex-landfill sites, particularly the ex-landfill that is located within the vicinity of urban settlement area should be given a 
priority to be developed as a recreational area. It is followed by the function of public park on ex-landfill as a contributor to the community's health (rank second), contributor to community's social security (rank third), contributor to enhancement of neighborhood areas (rank fourth) and as an added-value to the assets of surrounding area (rank fifth). Meanwhile, area for ecological conservation and nature preservation, social area (community gathering area), aesthetic value-added, contributor to community's wellbeing and buffer zone are ranked sixth to tenth in the function of public park on ex-landfill, as perceived by the community.

These results indirectly show that there are similar functions between public park at ex-landfill sites with the ordinary public park, which give more priority to outdoor recreation areas. However, in order to ensure that public park built on ex-landfill site could provide optimum benefits to the community, the type of recreation, either active or passive, should be determined. Hertzman et al. (1987) strongly believe that recreational activities must be determined in advance in order to minimize the exposure of park users to ex-landfill issues. These results also show that the community acceptance towards recreational area as the main priority function is related to the benefits to the community life, such as being proved by numerous earlier studies (Greenhalgh \& Worpole, 1995; Jolanda et al., 2006; IFPRA, 2012). Therefore, it is justified that the decision of the community to put the function as contributor to community's health in the second place and the function as contributor to the community's social security in the third ranking priority.

Meanwhile, the function of a public park at the ex-landfill as a contributor to the enhancement of neighborhood surrounding area, which is placed in rank fourth and function as added-value to the assets in the surrounding area, mainly the real estate assets in rank fifth show the perception of the community towards the positive impact of public park at ex-landfill development could generate comfort in their living environment. This perception is in accordance with the opinion of De Sausa (2003), which stated that local community generally has a positive perception towards the brownfield redevelopment as green space. According to him, it is common for the local community to associate the existence of green space with the increase benefits of social, economic and environment within their surrounding living area.

\section{Conclusion and Recommendations}

This study had produced an order of priority ranking for ex-landfill issues, the types of re-development, and the function of ex-landfill re-development as a public park. The rank of priority reflects what the Malaysian communities want for future development of ex-landfills. In general, this study showed the needs of the community to be given a chance to express their opinions in the nation's physical planning, especially in the redevelopment of ex-landfills, which is considered as a new planning component in Malaysia. It is necessary for the administrators as the main stakeholders to translate what the community has in mind related to planning. This could ensure the implementation of ex-landfill future redevelopment is supported by the community and to provide optimum benefits to the community.

As an outcome of this study, three orders of priority based on the ranking were developed to assist the Local Authority as the main administrator and stakeholder of ex-landfill redevelopment in Malaysia. The order of priority of ex-landfill issues may assist the Local Authority to identify and address the issues based on the scale of importance. The order of ex-landfill development type serves as the community's acceptance towards the proposed development plan for the Local Authority to think about. Besides, the order of the public park on the ex-landfill function will facilitate in planning, designing, and implementation of ex-landfill development as public parks. Therefore, in order to ensure the effectiveness of the function of the public park on ex-landfill, five functions in the rank of priority 1 to 5 were proposed: (i) recreational areas, (ii) contributor to the community's health, (iii) contributor to the community's social security, (iv) enhancement to the neighborhood environment, and (v) asset added-value to the surrounding area, which should become the criteria in the design.

With the support from Letang and Taylor's (2012) opinions, this study concludes that the need of the community's views and opinions to be considered in every planning stage, especially in ex-landfill planning, that is considered as a new field in Malaysia. This is because, the community, especially the local people, tends to know better on what they want to ensure that they obtain optimum benefits from the development that is proposed by the government. The involvement of the community in the ex-landfill redevelopment planning process will not only facilitate in developing effective development, but reflects the community support and acceptance towards the ex-landfill development policy. Therefore, it is proposed that the community should be given a chance to state their desires, either directly or indirectly, in every stage of ex-landfill planning process. Through this approach, it is anticipated that the 296 ex-landfills in Malaysia by 2020 will be planned effectively based on the needs of the community. Therefore, the concept of sustainable urban development through the 
planning of sustainable brownfield will be achieved and the development of ex-landfills as public parks could give a positive impact to the Malaysians' quality of life.

\section{References}

Abd. Mutalib, J. (1999). Garden city planning. In M. T. Osman, M. S. Mustafa Kamal, M. Norizan, A. B. Nordin, \& A. O. Abdul (Eds.), Towards Garden Nation: Vision and challenges. Kuala Lumpur: Institute of Landscape Architect Malaysia.

Adam, D., De Sausa, C., \& Tiesdell, S. (2010). Brownfield redevelopment: A comparison of North America and British approaches. Urban Studies, 47(1), 75-104. http://dx.doi.org/10.1177/0042098009346868

Armin, M. \& Hoda, R.N. (2013). The role of brownfield development in sustainable urban regeneration. Journal of Sustainable Development Studies, 4(2), 78-87.

Berman, L., \& Forrester, T. (2013). An indicator framework to measure effects of brownfield redevelopment on public health. Journal of Environmental Health, 76(1), 50-55.

Bernstan, M. K., Darlow, J. D, Deitch, L. B, Diggs, S. R., Ilitch, D., Nerman, A. F, Richner, A. C., Whit, K. E., \& Coleman, M. S. (2013). Public perception Technical Report: Hydraulic fracturing in the state of Michigan. MI: Graham Institute, University of Michigan.

Chun-Yang, S. Y., \& Talib, M. (2006). Overview of brownfields in Malaysia. Engineer Bulletin. Kuala Lumpur: Institute of Engineering Malaysia.

Dale, A., \& Newman, L. L. (2009). Sustainable development for some: Green environment and affordability. Local environment, 14, 669-681. http://dx.doi.org/10.1080/13549830903089283

Department of Town and Country Planning Peninsular Malaysia. (2010). National Urban Policy. Kuala Lumpur: Department of Town and Country Planning Peninsular Malaysia.

Department of Town and Country Planning Peninsular Malaysia. (2012). Planning guidelines for brownfield. Kuala Lumpur: Department of Town and Country Planning Peninsular Malaysia.

Department of Statistics. (2012). Population and housing census in Malaysia. Kuala Lumpur: National Printing Department.

De Sausa, C. (2003). Turning brownfield into green space in the city of Toronto. Landscape and Urban Planning, $62,181-198$.

Doerle, J. M. (2012). Economic perspectives of brownfield development in Germany: an integrated approach. Stuttgart: Department foe Environmental Protection, Germany.

Heartzman, C., Hayes, M., Singer, J., \& Highland, J. (1987). Upper Ottawa street landfill site health study. Environmental Health Perspectives, 75, 173-195.

Heberle, L., \& Werstedt, K. (2006). Understanding brownfield regenerations in the U.S. Local Environment, 11(15), 479-497.

Greenhalgh, L., \& Worpole, K. (1995). Park life: urban park and social renewals. London: Comedian Damos.

Ismail, N. (1999). Landskap Negara: ke arah merealisasikan Negara Taman. In M. T. Osman, M. S. Mustafa Kamal, M. Norizan, A. B. Nordin, \& A. O. Abdul (Eds.), Towards Garden Nation: Vision and challenges. Kuala Lumpur: Institute of Landscape Architect Malaysia.

IFPRA (International Federation of Parks and Recreational Administration. (2013). Benefits of urban parks: A systematic review. Copenhagen \& Almarp.

Jolanda, M., Verheij, R. A., Groewegen, P. P., Sjerp de Vries, \& Peter, S. (2006). Green space, urbanity and health: how strong is the relation? Journal of Epidemiology and Community Health, 60(7), 587-592.

Krejcie, R. V., \& Morgan, W. D. (1970). Determining sample size for research activities. Educational and Physiological Measurement, 30, 607-610.

Letang, S. J., \& Taylor, R. W. (2012). Community perception of redevelopment changes and its impacts on brownfields redevelopment success. International Journal of Sustainable Development, 5(11), 21-42.

Liu, Q. (2013). Urbanization and urban poverty in Southeast Asia. Beijing: The International Poverty Reduction Center in China.

Dali, M. Md., \& Awang, M. Z. (2006). Community perception on neighborhood park: towards the conservation of urban open space. Dynamics of Malaysia's urban society: Towards Sustainable Quality. Kuala Lumpur: 
Universiti Malaya Press.

Ministry of Housing and Local Government. (2004). The study of safe closure and rehabilitation of landfill sites in Malaysia. Kuala Lumpur: National of Housing and Local Government.

National Landscape Department. (2010a). Guideline to conserve ex-landfill as public parks. Kuala Lumpur: National Landscape Department.

National Landscape Department. (2010b). National Landscape Policy. Kuala Lumpur: National Landscape Department.

National Landscape Department. (2012). Public park directory in Malaysia. Kuala Lumpur: National Landscape Department.

National Physical Planning Council. (2004). Report of National Physical Planning No. 2/2004. Kuala Lumpur: Prime Minister Department.

National Solid Waste Department. (2012). Solid waste Lab 2012. Kuala Lumpur: National Solid Waste Department.

PEMANDU (Performance Management and Delivery Unit). (2010). Economic Transformation Programme: A roadmap for Malaysia. Putrajaya: Prime Minister Department.

Puteri Haryati, I., Melasutra, M. D., \& Safiah Yusmah, M. Y. (2013). Implementation of open space: The need for uniform policy. Journal of Sustainable Development, 6(7), 16-25.

RESCUE (Regeneration of European Sites in Cities and Urban Environments). (2005). Development of an analytical sustainability framework for the context of Brownfield Regeneration in France, Germany, Poland and UK. Retrieved from http://www.rescue.europe.com

Siikamaki, J., \& Wernstedt, K. (2008). Turning brownfields into green spaces: examing incentives and barrier to revitalization. Journal of Health Politics, Policy and Law, 33(3), 559-593.

United Nations Development Programme (UNDP) Malaysia. (2012). Malaysia urbanization. Retrieved June 1, 2014, from http://www.undp.gov.my

United States Environmental Protection Agency. (2002). Definition of brownfield sites. Section 101 of the Comprehensive Environmental Response, Compension and Liability. Act of 1980 (42 U.S.C 9601).

Zaini, Z., Sharifah Mastura. S. A., Jaafar, O., \& Madmud, M. (2011). Community perception of odor pollution from the landfill. Research Journal of Environmental and Earth Science, 3(2), 142-145.

\section{Copyrights}

Copyright for this article is retained by the author(s), with first publication rights granted to the journal.

This is an open-access article distributed under the terms and conditions of the Creative Commons Attribution license (http://creativecommons.org/licenses/by/3.0/). 